\title{
Analysis Of Community Satisfaction Index On Pt Adaro Indonesia's 5 CSR Programs In 2019
}

\author{
Aan Nurhadi ${ }^{1}$, Tien Zubaidah ${ }^{2}$, Syamsul Arifin $^{3}$, Laily Khairiyati ${ }^{4}$, Nita Pujianti ${ }^{3}$, Agung Waskito $^{4}$, Rudi \\ Fakhriadi $^{5}$, Noor Ahda Fadillah ${ }^{5}$, Siti Nurhayani ${ }^{6}$, Sherly Theana ${ }^{7}$ \\ ${ }^{1}$ Corporate Social Responsibility PT Adaro Indonesia, Balangan, \\ ${ }^{2}$ Ministry of Environmental Health, Polytechnic of Environmental Health, Ministry of Health, Republic of Indonesia \\ ${ }^{3}$ Department of Health Policy Administration, Public Health Study Program, Faculty of Medicine, University of Lambung Mangkurat \\ ${ }^{4}$ Department of Environmental Health, Public Health Study Program, Faculty of Medicine, University of Lambung Mangkurat \\ ${ }^{5}$ Department of Epidemiology, Public Health Study Program, Faculty of Medicine, University of Lambung Mangkurat \\ ${ }^{6}$ AKBID Banjarbaru \\ ${ }^{7}$ Public Health Study Program, Faculty of Medicine, University of Lambung Mangkurat
}

DOI: 10.29322/IJSRP.10.11.2020.p10731

http://dx.doi.org/10.29322/IJSRP.10.11.2020.p10731

\begin{abstract}
CSI (COMMUNITY SATISFACTION INDEX) measurement is one of the instruments that measuring level of service performance in the community. This instrument provides an opportunity for the community to be involved in the assessment of Performance FiveFieldfrom PT Adaro Indonesia's CSR objectively periodically as the basis for further planning. The purpose of this study is to analyze the community satisfaction index (CSI) in the CSR program of PT Adaro Indonesia in 2019. This type of research is survey through a cross-sectional approach. The population in this study was drawn from the beneficiaries of PT Adaro Indonesia's CSR program in 2019. The sample is the beneficiaries of PT Adaro Indonesia's CSR program which is consist of 5 fields, 26 clusters / programs, 907 respondents. CSI in 5 field of CSR, namely economy, education, health, socio-culture and the environment with the category satisfied (82.5). CSI the economic sector with the category satisfied (82.5), education with the category satisfied (83.84), the health sector with the category satisfied (79.4) socio-cultural field by category very satisfied (90.6), the environmental field with the category satisfied (81.9), there is an increase in CSI 5 in PT Adaro's CSR sector compared to 2014, 2018 and 2019. Suggestion, companies can maintain and improve the CSI so that will be better in the following year by increasing socialization and dissemination of information on CSR programs in the community
\end{abstract}

Index Terms- CSI, CSR, Adaro Indonesia

\section{INTRODUCTION}

A daro Indonesia, which is one of the coal companies in South Kalimantan.PT Adaro Indonesia as a leading coal mining company always complies with government policies. This includes the obligation to implement CSR programs in operational villages. The CSR program is not only carried out by Adaro, but also by its partners. The company synergizes with the government to contribute to human development since the company operates. PT Adaro Indonesia's CSR program is divided into 5 programs, namely economy, education, health, socio-culture and environment with the main target in the villages in the company's operational areas, 2 Provinces, 6 Districts, 15 Districts and 65 Villages according to the needs of the surrounding communities who are affected or have the opportunity to feel impact of industrial processes. The five pillars aim at creating an independent post-mining community in the sense of economic independence, intellectual independence and management independence with a value system of honesty, justice, simplicity, equality and non-discrimination based on the principles of participation, democracy, transparency, accountability and partnership.

CSR is not only a company's creative activity and is not limited to compliance with legal regulations alone, but is a company's commitment to building a better quality of life with related stakeholders (government and society), especially the community around the company. Because the role of CSR is currently increasingly important for the community around the company in an effort to balance development, be it economic, social, cultural health and the environment.

PT Adaro Indonesia's CSR activities are also the implementation of Law No. 40 of 2007 which regulates Limited Liability Company CSR, namely that the company established has a certain activity sector that emphasizes the aspects of community welfare. Activities in the course of its implementation, CSR has been widely accepted by the community in the company's operational villages and has had a positive impact, so that the community can benefit from the existence of the company in its area.

CSI measurement is one of the instruments used to analyze service performance in the community. This instrument provides an opportunity for the public to be involved in periodically assessing the Five Pillars Performance of PT Adaro Indonesia's CSR as a basis for further planning. A satisfied community is a very valuable asset because if the community is satisfied, it will continue to empower the company and will form a good perception to others about their good experiences (7).

The scope of measurement for CSI is guided by the Regulation of Permenpan 14 of 2017 concerning Guidelines for Preparing Community Satisfaction Surveys.

The previous regulations were deemed non-operational and required technical elaboration in their implementation. So it needs 
to be adjusted to an applicable survey method and easy to implement. In addition, this Regulation is intended to provide clear and firm directions and guidelines for service providers.

The elements will be the focus in implementing the Community Satisfaction Survey which consists of 9 elements consisting of requirements; systems, mechanisms and procedures; turnaround time; fees / rates; product type service specification; executive competence; implementing behavior; the handling of complaints; as well as facilities and infrastructure.

Measurement of the Community Satisfaction Index (CSI) is also useful for companies to support the preparation of future community development and empowerment plans, in accordance with the Minister of Energy and Mineral Resources Decree Number: 1824 / K / 30 MEM / 2018 concerning Guidelines for Implementation of Community Development and Empowerment (PPM), in addition to The CSI is also one of the items that must be in place for the fulfillment of the PROPER parameters of the Ministry of Environment and Forestry (KLHK) in accordance with the Minister of Environment and Forestry Regulation Number: 3/2013 and for the fulfillment of CSR Key Performance Indicators (KPIs) in making analytical bases for decision making with focus

\section{RESULTS AND DISCUSSION}

Table 1 Results of 5 Sector SMIs

\begin{tabular}{cccc}
\hline No. & Field & Score & Category \\
\hline 1 & Economy & 82.50 & Satisfied \\
2 & Education & 83.84 & Satisfied \\
3 & Health & 79.49 & Satisfied \\
4 & Socio-cultural & 90.66 & Very satisfied \\
5 & Environment & 81.90 & Satisfied \\
\hline & Total & $\mathbf{8 2 . 5 5}$ & Satisfied \\
\hline
\end{tabular}

Source: CSI Survey of ADARO CSR Program 2019

\section{Achievements of the CSI Program in the Economy}

CSI in the economic sector has a score 82.50 with the category very satisfied. Where there are 8 programs that are measured, namely the village development program, UMKM, agriculture, plantations, fisheries, livestock, village echoes, and economic infrastructure.The following is a comparison between the CSI in the economic sector in 2018 and 2019:

Table 2 Comparison between the CSI in the Economic Sector in 2018 and 2019

\begin{tabular}{llll}
\hline Field / Program & $\begin{array}{l}\text { CSI } \\
(\mathbf{2 0 1 8})\end{array}$ & $\begin{array}{l}\text { CSI } \\
\mathbf{( 2 0 1 9 )}\end{array}$ & Progress \\
\hline Village & 80 & 83.19 & +3.19 \\
Development & & & \\
UMKM & 77.5 & 83.96 & +6.46 \\
Agriculture & 80 & 85.49 & +5.49 \\
Plantation & 87.5 & 80.92 & -6.58 \\
Fishery & 77.5 & 77.99 & 0,49 \\
Ranch & 80 & 79.06 & -0.94 \\
Echo Village & 77.5 & 76.75 & -0.75 \\
Economic & 82.5 & 77.17 & -5.33 \\
Infrastructure & & & \\
\hline
\end{tabular}

on things that are considered the most important and can be measured.

The area for measuring the Community Satisfaction Index (CSI) is carried out in the village of PT Adaro Indonesia's operational area, namely in 6 districts, 15 districts and 28 CSR programs for measuring the Community Satisfaction Index, these are the company's operational village communities who have received benefits from the company's CSR program in 2018, namely beneficiaries of the five pillars, namely economic, education, health, socio-cultural and environmental programs.

\section{RESEARCH METHOD}

This research is analytic observational. The population in this study was drawn from the beneficiaries of the CSR program. The instrument or tool used in this research is a public perception questionnaire based on the Community Satisfaction Index (CSI) according to the Decree of the Minister of State Apparatus Empowerment No. KEP / 25 / M.PAN / 2/2004 concerning General Guidelines for Preparation of Community Satisfaction Index

\begin{tabular}{llll}
\hline Field / Program & $\begin{array}{l}\text { CSI } \\
\mathbf{( 2 0 1 8 )}\end{array}$ & $\begin{array}{l}\text { CSI } \\
(\mathbf{2 0 1 9 )}\end{array}$ & Progress \\
\hline Economy & 80 & 82.50 & +2.50 \\
\hline Source: CSI Survey of ADARO CSR Program 2019
\end{tabular}

From Table 2, it can be seen that the total value of CSI in the Economic Sector in 2019 has increased 2.5 compared to 2018. The Community Development Program, UMKM and Agriculture made a positive contribution to the increase in the achievements of CSI in the Economic Sector in 2019.

\section{Achievements of the CSI Program in the Field of Education}

CSI in education has a score 83.84 with the category very satisfied. Where there are 4 programs that are measured, namely the BUD IPB program, BUD UPN, regular scholarships, and educational infrastructure. The following is a comparison between the CSI in the education sector in 2018 and 2019:

Table 3. Comparison between the SME Education Sector in 2018 and 2019:

\begin{tabular}{llll}
\hline Field / Program & $\begin{array}{l}\text { CSI } \\
(\mathbf{2 0 1 8})\end{array}$ & $\begin{array}{l}\text { CSI } \\
\mathbf{( 2 0 1 9 )}\end{array}$ & Progress \\
\hline BUD IPB & 82.5 & 87.41 & +4.91 \\
UPN BUD & 75 & 82.60 & +7.60 \\
Regular & 77.5 & 85.42 & +7.92 \\
Scholarship & & & \\
Educational & 80 & 79.10 & -0.90 \\
Infrastructure & & & \\
\hline Education & 80 & 83.84 & +3.84 \\
\hline \multicolumn{4}{l}{ Source: CSI Survey of ADARO CSR Program 2019 }
\end{tabular}


From Table 3, it can be seen that the CSI value in the education sector in 2019 has increased in achievement by 3.84 Compared to the achievements in 2018. The BUD IPB program, BUD UPN and regular scholarships have contributed significantly to the improvement of the achievements of CSI in the education sector.

\section{Achievements of the CSI Program in the Health Sector}

The health sector CSI has a score 79.49with the category very satisfied. Where there are 6 programs that are measured, namely the KIBBLA program, cataract surgery, clean water, social health services, healthy schools, health infrastructure.The following is a comparison between the CSI in the health sector in 2018 and 2019:

Table 4 Comparison between the Health Sector CSI in 2018 and 2019

\begin{tabular}{llll}
\hline Field / Program & $\begin{array}{l}\text { CSI } \\
(\mathbf{2 0 1 8})\end{array}$ & $\begin{array}{l}\text { CSI } \\
(\mathbf{2 0 1 9})\end{array}$ & Progress \\
\hline KIBBLA & 80 & 76.86 & -3.14 \\
Cataract Surgery & 82.5 & 79.81 & -2.69 \\
Clean water & 70 & 78.92 & +8.92 \\
Health Service & 80 & 79.54 & -0.46 \\
Healthy School & 80 & 81.00 & +1.00 \\
Health & 75 & 80.61 & +5.61 \\
Infrastructure & & & \\
\hline Health & 77.5 & 79.49 & +1.99 \\
\hline Sour
\end{tabular}

Source: CSI Survey of ADARO CSR Program 2019

From table 4 it can be seen that the value of the CSI in the Health sector in 2019 has increased by 1.99 compared to the achievements in 2018. The Clean Water and Health Infrastructure Program contributed significantly to the improvement of the achievements of SMIs in the health sector.

\section{Achievement of CSI in Socio-Cultural Sector}

The CSI in the socio-cultural sector has a score 90.66 by categoryvery satisfied. Where there are 4 programs measured, namely religious programs, cultural arts, sports, and socio-cultural infrastructure. The following is a comparison between the CSI in the socio-cultural sector in 2018 and 2019:

Table 5 Comparison between the CSI in the SocioCultural Sector in 2018 and 2019

Now it is the time to articulate the research work with ideas gathered in above steps by adopting any of below suitable approaches:

\begin{tabular}{llll}
\hline Field / Program & $\begin{array}{l}\text { CSI } \\
(\mathbf{2 0 1 8})\end{array}$ & $\begin{array}{l}\text { CSI } \\
(\mathbf{2 0 1 9 )}\end{array}$ & Progress \\
\hline Religious & 80 & 99.96 & +19.96 \\
Art and culture & 85 & 84.55 & -0.45 \\
Sports & 75 & 87.91 & +12.91 \\
Socio-Cultural & 80 & 79.54 & +7.70 \\
Infrastructure & & & \\
\hline Socio-cultural & 80 & 90.66 & +10.66 \\
\hline \multicolumn{4}{l}{ Source: CSI Survey of ADARO CSR Program 2019 }
\end{tabular}

From Table 5, it can be seen that the value of CSI in the socio-cultural sector in 2019 experienced a significant increase, namely by $10.66 \%$ compared to the achievement in 2018. The Religious and Sports Program provided a significant contribution to increasing the achievements of CSI in the sociocultural field.

\section{Environmental Sector CSI Achievements}

Environmental CSI has a score 81.90 by category satisfied. Where there are 4 programs that are measured, namely reuse, reduce, recycle (3R), environmental education, Adiwiyata schools, and environmental infrastructure. Give itkut is a comparison between CSI in the socio-cultural field in 2018 and 2019:

Table 6 Comparison of CSI in the Environmental Sector in 2018 and 2019

\begin{tabular}{lllc}
\hline Field / Program & $\begin{array}{l}\text { CSI } \\
\text { (2018) }\end{array}$ & $\begin{array}{l}\text { CSI } \\
\mathbf{( 2 0 1 9 )}\end{array}$ & Progress \\
\hline 3R & 82.5 & 82.63 & 0.13 \\
Environmental & 77.5 & 83.48 & +5.98 \\
Education & & & \\
Adiwiyata School & & 82.81 & +12.91 \\
Environmental & & 78.79 & +7.70 \\
Infrastructure & & & \\
\hline Socio-cultural & 80 & 81.90 & +1.90 \\
\hline
\end{tabular}

Source: CSI Survey of ADARO CSR Program 2019

From table 6, it can be seen that the CSI value in the Environment sector in 2019 has increased by 1.90 compared to the achievements in 2018. In the CSI environmental infrastructure program in 2019 when compared to 2018 there was not much increase. 


\section{CONCLUSION}

1. CSI the economic sector with the category satisfied (82.50)

2. CSI the field of education with the category satisfied (83.84)

3. CSI health sector with the category satisfied (79.49)

4. CSI in the socio-cultural field by category very satisfied (90.66)

5. Environmental CSI with the category satisfied (81.90)

6. CSI in 5 areas of CSR, namely economy, education, health, socio-culture and the environment with the category satisfied (82.55)

7. CSI 5 in the CSR Sector of PT. Adaro was categorized as quite satisfied in 2014, so there was an increase in 2018 to the satisfied category. There was an increase in the indicators of satisfaction, namely the attributes of funding, behavior of implementers and handling of complaints, suggestions and input and infrastructure. Community Satisfaction Index Value in 5 CSR Areas of PT. Adaro in 2019 when compared to the previous year was still in the satisfied category, but in terms of value increased by 0.1 .

\section{REFERENCES}

[1] Irwanto AK, Prabowo A. 2009. Kajian efektivitas program corporate social responsibility (CSR) Yayasan Unilever Indonesia. Jurnal Manajemen1(1).

[2] Nirmaya GC, Muflikhati I, Simanjuntak M. 2014. Pengaruh Program Corporate Social Responsibility (CSR) Terhadap Kesejahteraan Keluarga Di Sekitar Tambang. Jurnal Ilmu Keluarga \& Masyarakat. Jan 1;7(1):19-29.

[3] Pohan IS. 2007. Jaminan mutu layanan kesehatan: dasardasar pengertian dan penerapan. Jakarta: EGC

[4] Sutowo IR. 2013. Analisis Indeks Kepuasan Masyarakat dan Manfaat Ekonomi Program Corporate Social Responsibility (CSR) Chevron Geothermal Salak, Ltd. Bidang Ekonomi di Kecamatan Pamijahan, Kabupaten Bogor.

[5] Wijono D. 2008.Paradigma dan metodologi penelitian kesehatan. Surabaya: CV Duta Prima Airlangga.

\section{AUTHORS}

First Author - Aan Nurhadi, Corporate Social Responsibility PT Adaro Indonesia, Balangan

Second Author - Tien Zubaidah, Ministry of Environmental Health, Polytechnic of Environmental Health, Ministry of Health, Republic of Indonesia

Third Author - Syamsul Arifin, Department of Health Policy

Administration, Public Health Study Program, Faculty of

Medicine, University of Lambung Mangkurat

Fourth Author - Laily Khairiyati, Department of

Environmental Health, Public Health Study Program, Faculty of Medicine, University of Lambung Mangkurat

Fifth Author - Nita Pujianti, Department of Health Policy Administration, Public Health Study Program, Faculty of

Medicine, University of Lambung Mangkurat

Sixth Author - Agung Waskito, Department of Environmental

Health, Public Health Study Program, Faculty of Medicine,

University of Lambung Mangkurat

Seventh Author - Rudi Fakhriadi, Department of Epidemiology, Public Health Study Program, Faculty of Medicine, University of Lambung Mangkurat

Eighth Author - Noor Ahda Fadillah, Department of Epidemiology, Public Health Study Program, Faculty of Medicine, University of Lambung Mangkurat

Ninth Author - Siti Nurhayani, AKBID Banjarbaru

Tenth Author - Sherly Theana, Public Health Study Program, Faculty of Medicine, University of Lambung Mangkurat

Correspondence Author - Aan Nurhadi, Corporate Social Responsibility PT Adaro Indonesia, Balangan, aan.nurhadi06@gmail.com 